\title{
Genetic Improvement of Local Red Peanut With Using Nuclear Technique (Multigamma Irradiation) for Obtaining Superior Variety
}

\author{
Bartholomeus Pasangka ${ }^{1} \&$ Refli $^{2}$ \\ ${ }^{1}$ Department of Physical and Agricultural Sciences, Nusa Cendana University, Indonesia \\ ${ }^{2}$ Department of Biology, Nusa Cendana University, Indonesia \\ Correspondence: Bartholomeus Pasangka, Department of Physical and Agricultural Sciences, Nusa Cendana \\ University, Indonesia. Tel: 62-822-3704-4338. E-mail: bpasangka15@gmail.com; b.pasangka@staf.undana.ac.id
}

\author{
Received: July 15, $2021 \quad$ Accepted: November 1, $2021 \quad$ Online Published: December 15, 2021 \\ doi:10.5539/jas.v14n1p94 URL: https://doi.org/10.5539/jas.v14n1p94
}

\begin{abstract}
The main problem examined in this study concerns the breeding of local red peanuts (Arachis hypogaea L.) to use standard multigamma irradiation methods to obtain superior variety that can be adapted to drought conditions, pests-diseases, extreme climate, and high production. The research objective was to develop local red peanut variety to use multigamma irradiation and careful selection for obtaining superior variety that can be adapted to drought conditions, pests-diseases, extreme climate, and high production. Research methods include multigamma irradiation, observation, sampling, carefully selection, comparative, and interpretation. The results of the study are as follows: The development of local red peanut variety through breeding to use multigamma irradiation and careful selection resulted in superior variety that could adapt to drought conditions, pests-diseases, extreme climate, and increased production significantly. The range of production of selected superior variety resulting from multigamma irradiation was (3.68-4.10) $\mathrm{t} \mathrm{ha}^{-1}$ with an average production of $3.92 \mathrm{t} \mathrm{ha}^{-1}$. The percentage increase in the production of selected superior variety was $49.23 \%$ with an average water content of dry seeds of $11.3 \%$.
\end{abstract}

Keywords: genetic, multigamma irradiation, nuclear technique, red peanut, superior variety

\section{Introduction}

\subsection{Main Problem Researched}

The main problem studied in this study was the improvement of cultivars of Malacca local red peanut seeds by utilizing multigamma (nuclear) irradiation to obtain superior cultivars that were able to adapt to drought stress, pests and high production. The advantage of this method is that it is possible to obtain superior cultivar varieties in a relatively short time and with several variations so that it makes it easier to carry out careful selection to obtain superior local red bean seed cultivars (Nopitasari et al., 2020; Yudiwanti et al., 2018; Prayitno et al., 2018; Purnowo et al., 2019). The conventional method of crossing up to F7 or F9 with a long enough time to get superior cultivars.

\subsection{Literature Study}

Peanuts (Arachis hypogaea L.) are the second most important legume after soybeans cultivated by farmer groups to fulfill food needs, the food industry, diversify people's food, and fulfill nutrition because peanuts have various properties such as: anti-cancer, anti-bacterial, antioxidant, improve function. red blood cells, swelling, increased appetite, back pain, and so on (Sutrisno \& Rozi, 2015; Rozi et al., 2016; Yulifianti et al., 2020; Purnamawati \& Manshuri, 2016; Radiati \& Sumarto, 2016).

\subsubsection{Productivity of Peanut}

Peanut cultivation in Indonesia is generally grown on dry land which dominated by Podzolic Red Yellow and Latosol content with a soil slope of less than $8 \%$, and can also be planted in alluvial and Regosol rice fields (Rahmianna et al., 2017; Marwiyah., et al., 2017; Harahap, 2021; Ratunggading et al., 2020; Setiono et al., 2018; \& Pujiastuti et al., 2021). The province of East Nusa Tenggara has a great opportunity for the development and cultivation of peanuts because it is dominated by dry land with an area of 18,396 ha available and the average peanut productivity is 1.12 t/ha (BPS NTT, 2020; Murdolelono, 2017; Puspita \& Tambunan, 2018; Zulchi, 2016). 
The average peanut productivity according to the results of research by Balitkabi (2016) is $2.61 \mathrm{t} / \mathrm{ha}$ and BPS NTT (2020) is $1.12 \mathrm{t} / \mathrm{ha}$ which is much lower. The average peanut production in Indonesia from 2014-2018 has relatively decreased, namely 638,896 t (2014), 605,449 t (2015), 570,470 t (2016), 495,447 t (2017), and 512,198 t (2018) (BPS, 2018). Especially in East Nusa Tenggara, peanut productivity is relatively low. The average yield of peanut productivity per hectare at the national level is around $1.29 \mathrm{t} / \mathrm{ha}^{6}$. BPS research results show that the national average peanut productivity is $1.3 \mathrm{t} / \mathrm{ha}$, so that in that year Indonesia has to import 130,000 tons of peanuts to meet domestic needs (BPS, 2018). The average productivity specifically for local red peanuts at the farm level is only $0.7 \mathrm{t} / \mathrm{ha}$. Note: $(\mathrm{t}=$ tons, $\mathrm{t} / \mathrm{ha}=$ tons/hectare $)$.

\subsubsection{Causes of Low Peanut Production}

The low productivity of peanuts in each region is caused by a variety of different factors, but in general, biotic and abiotic factors that affect growth, plant development and peanut production include (Seran \& Raharjo, 2018): (1) Superior seeds are still relatively lacking which is the dominant factor in the low productivity of local red peanut; (2) poor drainage; (3) excess water plants at the beginning of growth in paddy fields in the rainy season and drought in the dry season at the end of growth (Rohmah et al., 2020); (4) lack of key nutrients such as N, P, K, and Ca (Sarwanidas et al., 2014; Rahman et al., 2019; Kaya, 2012; Nopitasari et al., 2020; Yudiwanti et al., 2018); (5) competition with weeds in the vegetative growth phase, rarely or late; (6) shallow soil processing so that root growth and pod development are not optimal; (7) the seeds used have low growth capacity (not superior); and, (8) disease attacks such as bacterial wilt disease and fungal wilt, rust and leaf spot, peanut stripe virus (PStV) striped virus, as well as rats, whitefly, leafworms, pod borer, and nematodes (Prayitno et al., 2018).

\subsection{Problem Solving}

One method to solve the problem of low productivity of peanuts is the procurement of superior local peanut seeds that are sufficient for farmers to cultivate. One of the best methods for procuring superior local peanut seeds in a relatively short time is genetic improvement of local red peanut with using nuclear technique (multigamma irradiation).

\section{Method}

\subsection{Location of Research}

Sampling of local red peanuts from cultivation centers in Malaka, East Nusa Tenggara Indonesia. Irradiation of sample was carried out at the Mini Nuclear Laboratory of Bioscience Nusa Cendana University. The planting locations are concentrated in the Oesao farmer's garden, Fukdale East Kupang, and on the East Penfui demonstration plot.

\subsection{Research Instruments}

The main research instruments include: (1) Standard multigamma radiation source: sample irradiation; (2) Radiation dose counter: measures the multigamma radiation dose used; (3) Protein and fat content analysis tools; (4) Tractors: land cultivation; (5) Digital scale: weigh the mass of seeds; (6) Other supporting tools: crowbars, hoes, buckets, parallon pipes, pest sprayers, shovels, saws, hammers, sickles, etc.

\subsection{Research Methods}

The main method applied in research is irradiation: The sample of local red peanut form Malaka was irradiated by multigamma sources. Other supporting methods include: observation, sampling: for sampling and determining the location of planting (research), selection: select several times individually on peanut plants starting from the age of 1 month until the harvest is complete, purifying: carry out purification with careful selection in the second stage of research, comparability: comparing the characteristics of parent varieties with superior cultivars, and interpretation: interpret the research results that have been achieved. The advantage of this method is that the superior variety is obtained in a relatively short time and several variations of the superior varieties are obtained, so that it is easy to make the desired selection.

\subsection{Research Procedures}

The research procedures comprise of: (1) Conducting observations for the selection of local red peanut seeds from Malaka that to be developed by utilizing multigamma irradiation and determining the location for planting. At this stage, some important characteristics of the parent plant are observed and measured, such as plant height, resistance to pests and diseases, flowering age, fruit size (pods), harvest age, mass per 100 seeds, protein and fat content, etc.; (2) Cultivate the planting area by plowing using a tractor so that it is free from weeds and loose disturbances so that red peanuts grow well. Furthermore, the beds are made with a width of $100 \mathrm{~cm}$, a height of $30 \mathrm{~cm}$, the distance between the beds is $40 \mathrm{~cm}$, the width of the trench for the drainage system is $25 \mathrm{~cm}$; (3) 
Selected red peanut seed samples, then irradiated with a multigamma source at a dose of 3000 rads for 30 minutes; (4) Remove the cultivated land and let it dry again for two days (humid); (5) Irradiated local red peanut seeds are immediately planted on the prepared land with a spacing of $40 \mathrm{~cm} \times 15 \mathrm{~cm}$, the depth of the planting hole is $4 \mathrm{~cm}$, and each hole is filled with 4 seeds; (6) Irrigation after planting is adjusted to rainfall at the research site; (7) Observing the ability to grow and the age of growth in both the parent variety and the treatment. The number of seeds that did not grow in the selected sample was 100 seeds, both treatments were counted. Planting is done at the age of 7 days after planting; (8) Weed the plants and fertilize with NPK and Urea 2:1 so that the plants are free from weed disturbances and thrive (Rahman et al., 2019; Kaya, 2012; Novitasari et al., 2020); (9) Conduct a series of observations during plant growth including: pest-disease resistance, dry land adaptation, and plant selection. At the time of approaching the harvest period, another selection is carried out, measuring plant height, number of pods per tree, and number of seeds per pod. Conducting the 1 st selection at the age of 30 days after planting, the second selection when the fruit begins to fill solid, before harvest the Mn selection, and the last selection after harvest; (10) Harvest and drying. Harvesting is done after the pods are ripe well, which is marked by the dense contents and skin color of the pods that are dull, brownish black and coarse, by cutting them with a crowbar so that no pods are left in the soil. Count the number of pods per tree in a randomly recovered sample. After that, the pods are separated from the tree, drying the pods until they are dry; (11) At post-harvest mass measurement per 200 seeds, as well as analysis of water content; (12) Comparing the physical and chemical properties of superior mutant with parent varieties; (13) Interpret and conclusions.

The focus of the research for a year was genetic improvement of local red peanut cultivars with using multigamma irradiation to obtain superior mutant cultivar. Other variables observed and measured in the study were: Adaptive on dry land, pest and disease resistance, growth percentage, water content, production range, production mean, and production increase percentage.

\subsection{Statistics for Data Analysis}

Some of the mathematical formulations required include (Pasangka \& Refli, 2013a; Pasangka \& Refli, 2013b; Pasangka \& Refli, 2016; Pasangka \& Irvandi, 2021).

The percentage of growth on treatment sample is calculated by the equation:

$$
P G_{T S}=\left(\frac{T_{N S P}-T_{N S D G T S}}{T_{N S P}}\right) \times 100 \%
$$

Where, $P G_{T S}$ : growth percentage of treatment sample (\%); $T_{N S P}$ : total number of seeds planted; $T_{N S D G T S}$ : number of seeds that did not grow on treatment sample.

The formulation for calculating of growth percentage on control sample was:

$$
P G_{C S}=\left(\frac{T_{N S P}-T_{N S D G C S}}{T_{N S P}}\right) \times 100 \%
$$

Where, $P G_{C S}$ : growth percentage of control sample \%; $T_{N S D G C S}$ : number of seeds that did not grow on control sample.

The average production of selected superior variety in the three planting locations was calculated by the equation:

$$
A_{P T S}=\frac{P_{L 1}+P_{L 2}+P_{L 3}}{3}
$$

Where, $A_{P T S}$ : average production of treatment sample on three planting sites $\left(\mathrm{t} \mathrm{ha}{ }^{-1}\right) ; P_{L 1}, P_{L 2}, P_{L 3}$ : production of superior breed cultivars and control samples in three planting sites.

The average production in the control sample at the three planting sites is calculated by the equation:

$$
A_{P C S}=\frac{P_{L 1}+P_{L 2}+P_{L 3}}{3}
$$

Where, $A_{P C S}$ : average production of control sample at the three planting sites $\left(\mathrm{t} \mathrm{ha}^{-1}\right)$.

The percentage increase in the average production is calculated by the formula:

$$
I_{P A P}=\left(\frac{A_{P T S}-A_{P C S}}{A_{P T S}}\right) \times 100 \%
$$

Where, $I_{P A P}$ : Percentage of increase in production on selected superior cultivars. 


\section{Results}

\subsection{Results of Observations, Measurements, and Calculations}

This research was focused on the acquisition of superior variety of local red peanuts from Malaka. The real results obtained in the research or study are shown in the following Figures 1-4. The results of observations of seed initial growth in the treatment and control samples to calculate the percentage growth, various physical and chemical characteristics that were observed, measured, and calculated, as well as the estimated production rate, were presented respectively in Tables 1-3.

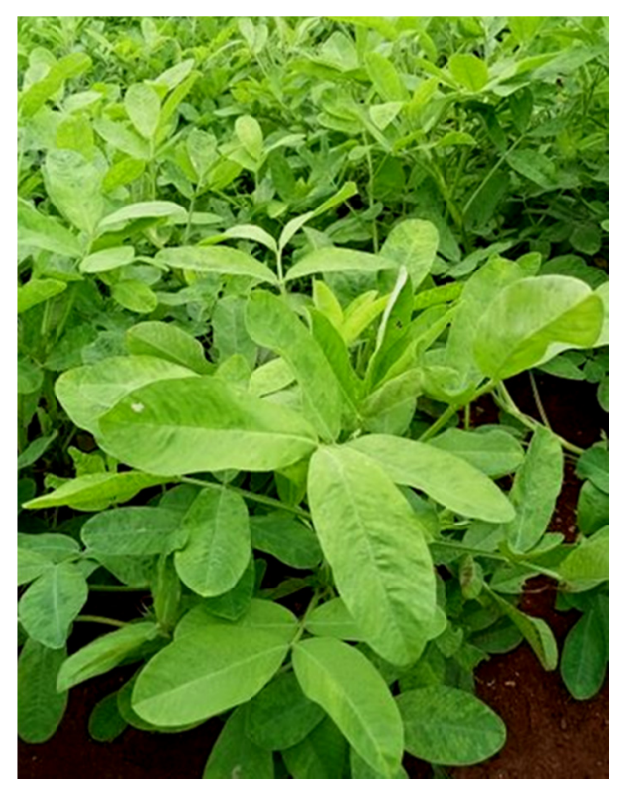

Figure 1. An example of selected superior variety resulting from multigamma irradiation of local red peanut from Malaka on $40 \mathrm{~d}$ a p

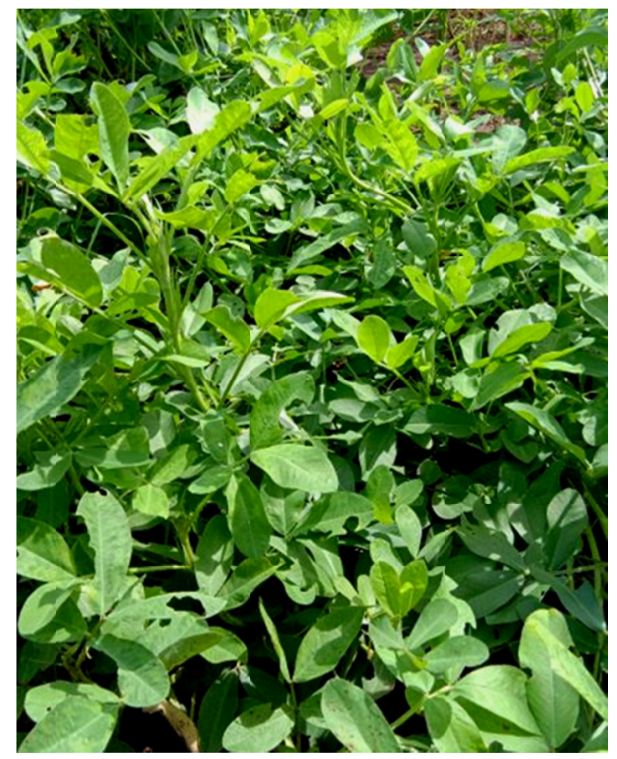

Figure 2. An example of initial variety of local red peanut from Malaka on 40 days after planting (d a p) 


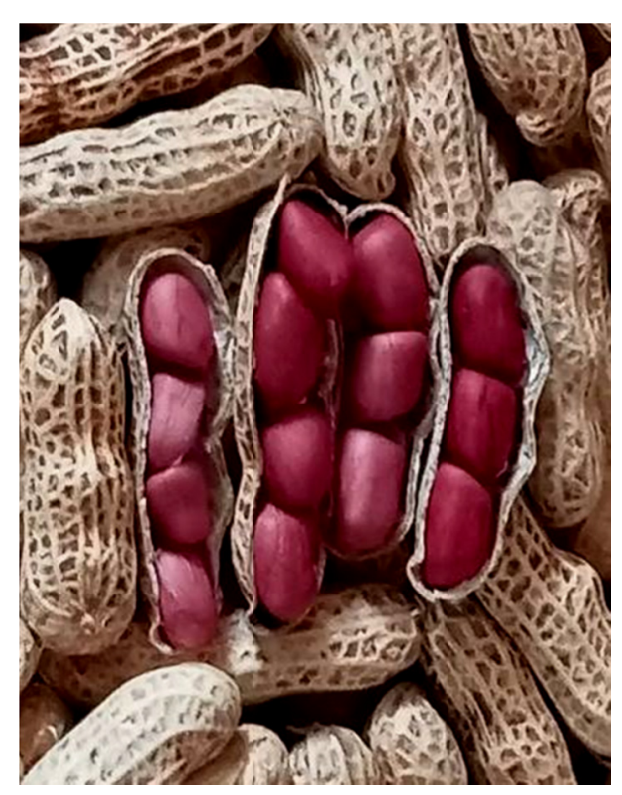

Figure 3. An example of seeds and pods of selected superior variety of local red peanut from Malaka

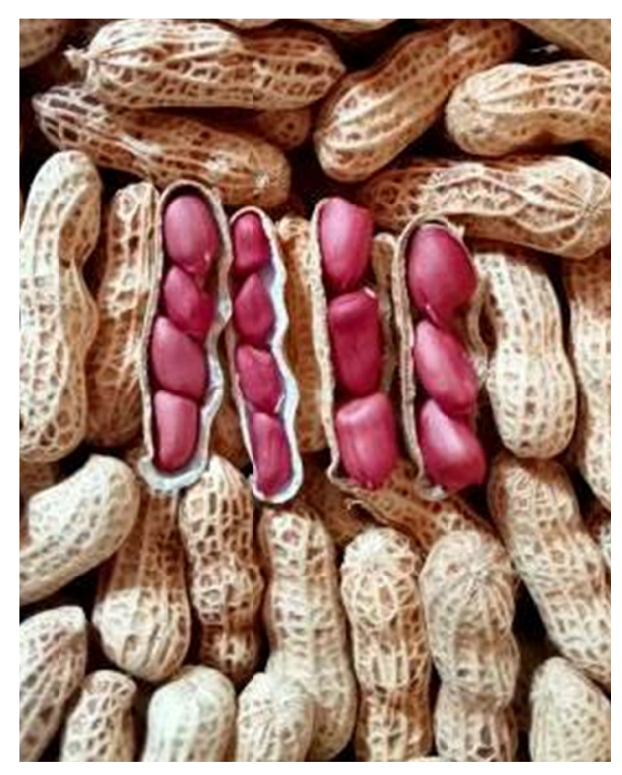

Figure 4. An example of seeds and pods of initial variety of local red peanut from Malaka 
Table 1. The number of seeds that did not grow in the control and the treatment samples

\begin{tabular}{|c|c|c|c|c|c|c|c|c|c|c|c|c|}
\hline \multirow{3}{*}{ GS } & \multirow{3}{*}{$\begin{array}{l}\text { The total number of } \\
\text { seeds on every group }\end{array}$} & \multirow{3}{*}{$\mathrm{CS}$} & \multicolumn{10}{|c|}{ The number of seeds was not grown } \\
\hline & & & \multicolumn{10}{|c|}{ Treatment Sample } \\
\hline & & & 1 & 2 & 3 & 4 & 5 & 6 & 7 & 8 & 9 & 10 \\
\hline I & 100 & 18 & 3 & 5 & 3 & 4 & 6 & 3 & 5 & 4 & 3 & 3 \\
\hline II & 100 & 16 & 2 & 1 & 5 & 3 & 5 & 4 & 3 & 2 & 5 & 4 \\
\hline III & 100 & 22 & 1 & 3 & 1 & 3 & 2 & 3 & 3 & 5 & 1 & 3 \\
\hline IV & 100 & 19 & 4 & 3 & 2 & 1 & 1 & 2 & 1 & 1 & 3 & 2 \\
\hline \multirow[t]{5}{*}{ V } & 100 & 23 & 3 & 1 & 3 & 2 & 2 & 2 & 2 & 3 & 2 & 1 \\
\hline & Average $=100$ & 19.60 & 2.60 & 2.40 & 2.80 & 2.60 & 3.20 & 2.80 & 2.80 & 3.00 & 2.80 & 2.60 \\
\hline & Average total mutants & & & & & & 2.56 & & & & & \\
\hline & Growth Percentage (\%) & 80.40 & 97.40 & 97.60 & 97.20 & 97.40 & 96.80 & 97.20 & 97.20 & 97.00 & 97.20 & 97.40 \\
\hline & Average Percentage (\%) & 80.40 & & & & & 97.44 & & & & & \\
\hline
\end{tabular}

Note. GS: Group of Samples; CS: Control Sample.

Table 2. Important physical and chemical characteristics observed, measured, and calculated in selected superior varieties resulting from multigamma irradiation and initial varieties.

\begin{tabular}{|c|c|c|c|}
\hline No. & Description & Control Sample & Treatment Sample \\
\hline 1 & Growth time & $11 \mathrm{~d} \mathrm{ap}$ & $5 \mathrm{~d}$ a p \\
\hline 2 & Growth percentage & $80.40 \%$ & $97.44 \%$ \\
\hline 3 & Ranges of flowered age & $43-50 \mathrm{~d}$ a p & $28-40 \mathrm{~d}$ a $\mathrm{p}$ \\
\hline 4 & Average of flowered age & $46 \mathrm{~d}$ a p & $38 \mathrm{~d}$ a p \\
\hline 5 & Leaf color & Yellowish green & Light dark green \\
\hline 6 & Flower color & Yellowish & Yellow \\
\hline 7 & Ranges of high plant & $26-56 \mathrm{~cm}$ & $45 \mathrm{~cm}-86 \mathrm{~cm}$ \\
\hline 8 & Average of high plant & $48 \mathrm{~cm}$ & $68 \mathrm{~cm}$ \\
\hline 9 & Ranges of harvest age & $93 \mathrm{~d}$ a $\mathrm{p}-135 \mathrm{~d}$ a $\mathrm{p}$ & $62 \mathrm{~d}$ a p-92 d a p. \\
\hline 10 & Average of harvest age & $115 \mathrm{~d}$ a p & $82 \mathrm{~d}$ a p \\
\hline 11 & Ranges of pods number per tree & (21-61) pod per tree & $(48-123)$ pods per tree \\
\hline 12 & Average of pods number per tree & 41 pods per tree & 81 pods per tree \\
\hline 13 & Ranges of seeds number per pod & $1-4$ seeds per pod & $1-5$ seeds per pod \\
\hline 14 & Average of seeds number per pod & 2 seeds per pod & 3 seeds per pod \\
\hline 15 & Skin color of dry pods & brown & light brown \\
\hline 16 & Seed color & red & light red \\
\hline 17 & Ranges of mass for 200 seeds (g) & $64.6-93.6$ & $98.4-124.8$ \\
\hline 18 & Average of mass for 200 seeds (g) & 71.2 & 112.2 \\
\hline 19 & Adaptation to land with less water (dry), lime and high salt & Less adaptive & adaptive \\
\hline 20 & Adaptation to pests and diseases & less adaptive & Especially addictive is rust, specks and leaf beetles \\
\hline 21 & Water contents $(\%)$ & $11-19$ & $10.2-12.5$ \\
\hline 22 & Average of water contents $(\%)$ & 16.5 & 11,3 \\
\hline 23 & Production ranges $\left(\mathrm{t} \mathrm{ha}^{-1}\right)$ & $(1.86-2.15)$ & $(3.68-4.10)$ \\
\hline 24 & Average of production $\left(\mathrm{t} \mathrm{ha}^{-1}\right)$ & 1.99 & 3.92 \\
\hline 25 & Increasing percentage of production (\%) & - & $49.23 \%$ \\
\hline 28 & Potential of maximum production $\left(t \mathrm{ha}^{-1}\right)$ & 2.15 & 4.10 \\
\hline
\end{tabular}

Note. $\mathrm{d}$ a $\mathrm{p}=$ days after planting, $\mathrm{t} \mathrm{ha}^{-1}=$ tons hectare $^{-1}$.

Table 3. Production rates at three planting sites in control samples and treatment samples (treatment $=$ selected mutants).

\begin{tabular}{llll}
\hline No. & Planting Location & Control Sample $\left(\mathrm{t} \mathrm{ha}^{-1}\right)$ & Treatment Sample $\left(\mathrm{t} \mathrm{ha}^{-1}\right)$ \\
\hline 1 & Oesao & 1.86 & 3.68 \\
2 & Fukdale & 1.95 & 3.98 \\
3 & East Penfui & 2.15 & 4.10 \\
\hline & Average production & 1.99 & 3.92 \\
& Increasing percentage of production $(\%)$ & - & $49.23 \%$ \\
\hline
\end{tabular}


To calculate the percentage of growth, 5 groups were taken randomly with 100 seeds observed in each group. The treatment sample was taken 5 groups with 10 variations of observation.

\subsection{Statistical Calculations}

The percentage of seed growth in control and treatment samples can be calculated based on equation (1) and the data in Table 1, as follows. The number of seeds observed that were randomly selected was 100 seeds, the mean of seeds that did not grow in the control sample was 19.60 seeds. The mean of seeds that did not grow in the selected mutant varieties was 2.56 seeds. The percentage of growth in the treated sample (treatment or seed irradiated with a multigamma source) is:

$$
P G_{T S}=\left(\frac{T_{N S P}-T_{N S D G T S}}{T_{N S P}}\right) \times 100 \%=\left(\frac{100-2.56}{100}\right) \times 100 \%=97.44 \%
$$

Percentage of growth in control samples:

$$
P G_{C S}=\left(\frac{T_{N S P}-T_{N S D G C S}}{T_{N S P}}\right) \times 100 \%=\left(\frac{100-1.96}{100}\right) \times 100 \%=80.40 \%
$$

The average production of treated samples or selected superior variety resulted from multigamma irradiation at the three planting sites:

$$
A_{P T S}=\left(\frac{P_{L 1}+P_{L 2}+P_{L 3}}{3}\right)=\left(\frac{3.68+3.98+4.10}{3}\right)=3.92 t h a^{-1}
$$

The average production in control samples (parent varieties) at three planting locations:

$$
A_{P C S}=\left(\frac{P_{L 1}+P_{L 2}+P_{L 3}}{3}\right)=\left(\frac{1.86+1.95+2.15}{3}\right)=1.99 t h a^{-1}
$$

The percentage increase in production in selected superior varieties resulted from multigamma irradiation:

$$
I_{P A P}=\left(\frac{A_{P T S}-A_{P C S}}{A_{P T S}}\right) \times 100 \%=\left(\frac{3.92-1.99}{3.92}\right) \times 100 \%=49.23 \%
$$

\section{Discussion}

\subsection{Growing Time, Growth Percentage, Flowering Age, and Climate Extremes (Regulated) and Land Conditions Lacking Water (Drought)}

The results of observations, measurements, and calculations on the initial variety and selected superior variety showed that the growing time of the initial variety was 11 days after planting ( $\mathrm{d}$ a $\mathrm{p})$, while the selected superior variety was $5 \mathrm{~d}$ a p. The percentage of growth of selected superior variety was $97.44 \%$, while the percentage of growth in initial variety was $80.40 \%$. The average flowering age of selected superior variety was $38 \mathrm{~d}$ a $\mathrm{p}$ and the average flowering age of the initial variety was $46 \mathrm{~d}$ a $\mathrm{p}$. This indicated that the selected superior variety resulting from multigamma irradiation had a higher growth percentage and flowered faster than the initial variety.

Figure 1 shows an example of the growth of red peanut from Malaka, selected superior variety resulting from multigamma irradiation at the age of $40 \mathrm{~d}$ a $\mathrm{p}$ with leaves that appear to be flourishing and smooth. Figure 2 shows an example of local red peanuts of initial variety from Malaka at the age of $40 \mathrm{~d}$ a p , which has smaller leaves than the selected superior variety. Figure 3 shows an example of seeds and pods of selected superior variety that have 3 and 4 seeds as well as the dry seeds of local red peanuts from Malaka, which have been carefully selected from post-harvest, which look dense and smooth. This indicates that local red peanuts from Malaka as a resulting from multigamma irradiation can adapt to less watery land (planted in dry seasons) and extreme climate, are tolerant of pests and diseases, and have a high production probability. Behind that, Figure 3 shows an example of pods that have 3 and 4 seeds and the dry seeds of local red peanuts from Malaka which have been carefully selected by post-harvest which have a higher number of seeds per pod than the initial variety, while Figure 4 shows an example of pods and dry seeds of local red peanut of initial variety from with fewer seeds per pod than the selected superior mutant varieties resulting from multigamma irradiation. This shows that the local red peanut which selected superior variety from Malaka resulting from multigamma irradiation have a higher production than the parent variety.

\subsection{Range and Average Plant Height, Range and Average Age of Flowering and Harvesting of Local Red Peanuts}

Local red peanuts, selected superior variety resulting from multigamma irradiation have a height ranging from $45-86 \mathrm{~cm}$, while the initial variety is $26-56 \mathrm{~cm}$ with an average plant height of $68 \mathrm{~cm}$ for the selected superior 
variety and $48 \mathrm{~cm}$ for the initial variety. Flowering age ranges for selected superior variety $28-40 \mathrm{~d}$ a p, the initial variety $43-50 \mathrm{~d}$ a $\mathrm{p}$, with an average flowering age of $38 \mathrm{~d}$ a p for selected superior variety and $46 \mathrm{dd}$ a $\mathrm{p}$ for initial variety. The harvesting ages ranged from 62-92 $d$ a $p$ for selected superior variety and 93-135 $d$ a $p$ for initial variety. The average age of harvest for selected superior variety was $82 \mathrm{~d}$ a $\mathrm{p}$ and the initial variety was $115 \mathrm{~d}$ a $\mathrm{p}$. These results show that the local red peanut from Malaka for selected superior variety resulting with multigamma irradiation has a shorter harvest life than the initial variety.

4.3 Range and Average Number of Pods, Range and Average Number of Seeds, Range and Average Mass per 200 Seeds

The number of pods per tree in local red peanut, selected superior variety resulted from multi gamma irradiation (8-21) pods per tree, the initial variety (21-61) pods per tree with an average number of pods per tree 81 pods per tree for selected superior variety and 41 pods per tree for initial varieties. The ranges and average number of seeds per pods for selected superior variety and initial variety respectively were: (1-5) seeds per pod, (1-4) seeds per pod, 3 seeds per pod and 2 seeds per pod.

The range and mass average per 200 seeds of selected superior and initial varieties respectively were (98.4-124.8) g, (64.6-93.6) g, $112.2 \mathrm{~g}$, and $71.2 \mathrm{~g}$. So, it can be argued that the mass per 200 seeds in the selected superior variety is higher than the initial variety.

\subsection{Range and Average Production, Percentage of Additional Production, and Water Content}

Production of local red peanuts for selected superior variety resulting from multigamma irradiation ranged from (3.68-4.10) $\mathrm{t} \mathrm{ha}^{-1}$ and initial variety (1.86-2.15) $\mathrm{t} \mathrm{ha}^{-1}$. The maximum production potential is $4.10 \mathrm{t} \mathrm{ha}^{-1}$ for selected superior variety and $1.99 \mathrm{t} \mathrm{ha}^{-1}$ for initial variety. The average production of selected superior variety was $3.92 \mathrm{t} \mathrm{ha}^{-1}$ and $1.99 \mathrm{t} \mathrm{ha}^{-1}$ for initial variety. The percentage increase in the production of selected superior variety was $49.23 \%$. The range and average water content of selected superior variety resulting from multigamma irradiation and parent variety respectively were $(10.2-12.5) \%,(11-19) \%, 11.3 \%$, and $16.5 \%$, respectively. The above results indicate that the production of selected superior variety resulting from multigamma irradiation increased significantly with the percentage of water content according to the standard.

\section{Conclusion}

Based on the description in the discussion section, the following conclusions can be stated as follows. The development of local red peanut variety from Malaka through breeding with using of multigamma irradiation and careful selection resulted in selected superior variety that could adapt to dry condition, extreme climate, pests-diseases, and increased production significantly.

The range of production of selected superior variety resulting from multigamma irradiation was (3.68-4.10) $\mathrm{tha}^{-1}$ with an average production of $3.92 \mathrm{tha}^{-1}$. The percentage increase in the production of selected superior variety resulting from multigamma irradiation was $49.23 \%$ with an average water content of dry seeds of $11.3 \%$.

\section{Acknowledgements}

This research or study was supported and funded by Decentralization research, Directorate of Research and Public Service, Department of Education and Culture of Indonesia Government, March 2018-March 2021 with Research agreement letter (Research grant) No. 118a/UN15.PPKKTR/VI/2019. Especial thanks to Government of Indonesia has been funded of this research and also especial thanks to co-Author who has collaborated with the author in all research activities and writing publication articles.

\section{References}

Balitkabi. (2016). Description of Superior Peanut Varieties (KT.45).

BPS. (2018). Peanut Production by Province. Results of Coordination Meeting in Solo (pp. 25-27).

BPS NTT. (2020). East Nusa Tenggara Number 2020. Retrieved July 15, 2021, from http://www.ntt.bps.go.id

Harahap, F. S. (2021). Evaluation of Land Suitability for Peanut Plantation in Pardamean Village, Rantau Selatan District, North Sumatra. Agroplasma Journal, 8(1), 11-17. https://doi.org/10.36987/agroplasma.v8i1.2093

Kaya, E. (2012). Effect of Potassium and Phosphate Fertilizers on Availability and Phosphate Uptake of Peanut (Arachis hypogaea L.) Plants in Brunizem Soil. Agrologia, 1(2), 113-118.

Marwiyah, S., Purnawati, H., \& Sembiring, P. (2017). Physical Mutation Induced by Gamma Ray Irradiation on Kidney Bean. Journal Comm. Hort. J., 1(4), 49-55. https://doi.org/10.29244/chj.1.1.49-55 
Murdolelono, B. (2017). Legumes Crop Technology for Farmers in East Nusa Tenggara. Proceeding of Research on Various Peanut and Tuber Crops.

Nopitasari, L., Siswoyo, \& Azhar. (2020). Utilization of Peanut Waste (Arachis hypogaea L) as Organic Fertilizer on Green Mustard Plants in Carangan District, Garut Regency, West Java. Journal of Agricultural Innovation, 1(3), 219-230. https://doi.org/10.47492/jip.v1i3.69

Pasangka, B., \& Refli. (2013a). Developing of Local Peanut Based on Multiculture that Tolerant to Abiotic and Biotic Conditions with Multigamma Radiation Method (Nuclear). Journal of Agricultural Science, 5(5), 15-26. https://doi.org/10.5539/jas.v5n5p15

Pasangka, B., \& Refli. (2013b). The Application of Multigamma Radiation as a Physical Mutagen for Breeding of Local Soybean. Journal of Agricultural Science, 5(6), 201-210. https://doi.org/10.5539/jas.v5n6p201

Pasangka, B., \& Refli. (2016). Development and ultivation of Local Kidney Bean (Phaseolus vulgaris L.) Through Breeding to Use Multigamma Irradiation Technique (Nuclear). American Journal of Agricultural and Biologycal Sciences, 11(3), 117-127. https://doi.org/10.3844/ajabssp.2016.117.127

Pasangka, B., \& Irvandi, G. P. (2021). Continuous Development and Cultivation of Soybean as a Result of Multigamma Irradiation through Final Purifying Method. Journal of Research in Science Education, 7(2), 156-166. https://doi.org/10.29303/jppipa.v7i2.611

Prayitno, W. E., Kusumaningrum, H. D., \& Lioe, H. N. (2018). Peanut Storage Condition and Aspergillus flavus Contamination Potential at Traditional Market Retailers in Jakarta Area. Agritech, 38(1), 45-55. https://doi.org/10.22146/agritech.26113

Pujiastuti, E. S., Siahaan, F. R., Tampubolon, J. R., Tarigan, J. R., \& Sumihar, S. T. T. (2021). Response of Soil and Peanut on the Application of Several Local Microorganism and Manures. Journal of Agrotechnology and Plantation: Agrinula, 4(1), 1-12. https://doi.org/10.36490/agri.v4i1.107

Purnamawati, H., \& Manshuri, A. G. (2016). Source and Sink in Peanut Plants (Monograph Book, pp. 84-93).

Purnowo, J., Sugianingsih, S., \& Satia, T. A. (2019). Partnership Analysis Between Peanut Famers and CV Mitra Priyangan Case at Peanut Farmer on Sindangbarang Cianjur. Journal NeO-Bis, 3(2), 110-128.

Puspita, D. E., \& Tambunan, S. B. (2018). Growth and Production Capacity of Four Peanut Varieties (Arachis hypogea L.). Serambi Saintia, VI(2), 26-31.

Radiati, A., \& Sumarto. (2016). Analysis of Physical Properties, Organoleptic Properties, and Nutritional Values of Tempeh from Non-Soybean Legumes. Journal of Food Technology Applications, 5(1), 16-22.

Rahman, N., Suntoro, \& Sakya, A. T. (2019). Peanut Growth and Gynophore Formation on Boron and Phosphor Applications. Soil Science, 16(1), 57-66. https://doi.org/10.20961/stjssa.v16i1.25372

Rahmianna, A. A., Pratiwi, H., \& Harnowo, D. (2017). Peanut Cultivation, Research Institute for Various Peanut and Tuber Crops. Balitkabi Monograph, 13, 133-169.

Ratunggading, F., Jawang, J. P., \& Nganji, M. U. (2020). Evaluation of Land Potential for the Development of Peanut in Haharu District East Sumba East Nusa Tenggara Indonesia. Journal of Agricultural Sciences: Agriland, 8(3), 261-266. https://jurnal.uisu.ac.id/index.php/agriland

Rohmah, H. F., Suwarto, \& Muliasari, A. A. (2020). Optimization of Oil Palm Replanting Land with Corn and Peanut Intercropping System (Arachis hipogaea L.). Symmetric Journal, 10(1), 256-262. https://doi.org/ $10.31959 /$ js.v10i1.199

Rozi, F., Sutrisno, I., \& Rahmianna, A. A. (2016). Peanut Development Opportunities in Dry Land of East Nusa Tenggara. Bulletin Palawija, 14(2), 71-77.

Sarwanidas, T., Syamsuddin, \& Arabia, T. (2014). Potassium Application to Peat Soilon Yield and Seeds Vigor and Viability of Several Peanut Varieties. J. Floratek, 9, 93-101.

Seran, A. H., \& Raharjo, K. T. P. (2018). Study of Drought Stress after Flowering Period of Red Bean (Phaseolus vulgaris L.) on Entisol Soil. Journal of Dryland Conservation Agriculture, 3(3). https://doi.org/10.32938/ sc.v3i03.331

Setiono, Syarif, A., \& Syarif, Z. (2018). Peanut Growth Response to Cow Manure and Dolomite in Acid Soil. Journal of Sciences: Agro, 3(1), 1-9. Retrieved from http://ojs.umb-bungo.ac.id/index.php/saingro/index 
Sutrisno, I., \& Rozi, F. (2015). Local Wisdom as the Basis for Optimization of Food Crop Cultivation in East Sumba. Development of Environmental-Friendly Local Resources Potential for Strengthening Global Competitive National Agricultural Products (pp. 247-255). Research Institute for Various Nuts and Tubers.

Yudiwanti, Sudarsono, Purnamawati, H., Yusnita, \& Hapsoro, D. (2018). Current Status of Peanut Breeding at Bogor Agricultural University. Proceedings of the Seminar on Research Results of Legumes and Tubers in Malang Agricultural R\&D (pp. 152-161).

Yulifianti, R., Santosa, B. A. S., \& Widowati, S. S. (2020). Processing Technology and Processed Peanut Products (pp. 376-393). Research Center for Various Nuts and Tubers Malang, and the Center for Agricultural Postharvest Research and Development Bogor.

Zulchi, T. (2016). Peanut Production Potential, Planta Tropika Journal of Agro Science, 4(1), 37-45. http://doi.org/10.18196/pt.2016.055.37-45

\section{Copyrights}

Copyright for this article is retained by the author(s), with first publication rights granted to the journal.

This is an open-access article distributed under the terms and conditions of the Creative Commons Attribution license (http://creativecommons.org/licenses/by/4.0/). 